\title{
Study on the Role of Stakeholders in Value Creation of Smart Tourism Construction
}

\author{
Qian Jiang \\ School of management, Wuhan University of Technology, Wuhan 430070, China \\ Jiangqian1210@163.com
}

Keywords: Game, value creation, smart tourism.

\begin{abstract}
According to the research status of smart tourism and problems existing in the construction of smart tourism in our country, from the perspective of stakeholders, a value creation model of government, tourism development enterprises and tourists participating in smart tourism construction is built. Through building the game model, the game's Nash equilibrium is analyzed. The result of the game shows that in the early stage of the construction of smart tourism, the government's advocacy support plays a leading role, but excessive subsidy will break the balance situation; tourism development enterprises should recognize the prospects of smart tourism, and take the initiative to construct smart tourism; tourists although in a certain disadvantaged position, but its ancillary role is irreplaceable.
\end{abstract}

\section{Introduction}

Economic society are undergoing radical changes in recent years. It is of vital importance to understand and adapt to the power of extreme technologies and use them to gain a competitive advantage. Especially in tourism, technology-driven innovation has had a huge impact on the development of the industry. In the academic circle, the concept and evaluation of smart tourism have been explored in many ways. However, as a complex systematic project, the construction of smart tourism is still at an early stage. Under the innovation 2.0 paradigm, the boundaries of various stakeholders in the construction of smart tourism are constantly "ablated" by functional technologies such as ICTs. Giacomo Del Chiappa and Rodolfo Baggio (2015) combined the popular diffusion model with other network analysis methods and applied them to explore the function of ICTs in promoting the transfer of knowledge among stakeholders, thus enhancing the innovation process in tourist destinations. Kim Boes and Dimitrios Buhalis (2017) have explored the core elements of smarte tourism destinations based on service-led logic that provide managers with the strategic tools to implement innovation in smart tourism construction, so as to create value for all stakeholders. The goal of smart tourism construction is not to realize the respective interests of all economic subjects but to realize the co-creation of values through more immediate information exchange and resource sharing. This paper is to explore the role of various stakeholders in smart tourism construction.

\section{Value Creation Models}

\subsection{Participation of Stakeholder in Smart Tourism Construction}

Smart construction stakeholders are any entities, organizations or individuals that have an impact on, are influenced, or benefit from the fruit of the construction. Lian Tonghui (2016) summarized the related research of smart tourism construction, and concluded that the main body of smart tourism construction involves the government, enterprises and tourists. Zhang Xiuqin (2017) defines stakeholders in different stages of the development of China's tourism industry. As a new format combining traditional tourism and information technology industry, the core stakeholders include tourists, tourism enterprises, governments and communities.

\subsection{Analysis of the Role of Stakeholders in Smart Tourism Construction}

Although there are many stakeholders involved in smart tourism, tourists are the most crucial stakeholders according to the scholars' description of the concept of smart tourism. At the same time, combined with the actual situation of the development of China's smart tourism, the construction of 
smart tourism is still in its infancy, and has not yet produced a mature example of smart tourism. Therefore, the government's regulation and support are indispensable. Therefore, this paper selects tourism development enterprises, tourists and government as the most important stakeholders in the construction of smart tourism.

In the early stages of the smart tourism development, government formulate and promulgate some relevant policies and documents that promote, guide and regulate smart tourism construction. In addition, certain subsidies which play a good role in promoting the construction of smart tourism are provided. Tourists are the ultimate users of smart tourism and why enterprise develop smart tourism is to improve the tourists' travel experience. Therefore, it is important to understand the preference of "new" tourists in the smart tourism construction. In the process of building a smart tourism, if tourists are not involved, smart tourism construction will inevitably fail, which is a common problem in China's current smart tourism construction. In response to the government's policy initiatives, enterprises implemented smart tourism construction and continuously improved based on collected visitor data and tourists' suggestions. The tourism enterprises, government, tourists through the integration and linkage of information technology, seek common development solutions, share the fruits of development and promote the sound and orderly development of smart tourism.

\subsection{Value Creation Model of Stakeholders}

Smart tourism should be constructed based on geographical location features and population of scenic area, not the stereotyped pattern. Different scenic areas have different smart tourism demands. Under the influence of ICTs, the stakeholders in the construction of smart tourism have more diversified functions. This paper proposes the value creation model which government, enterprises and tourists are involved.

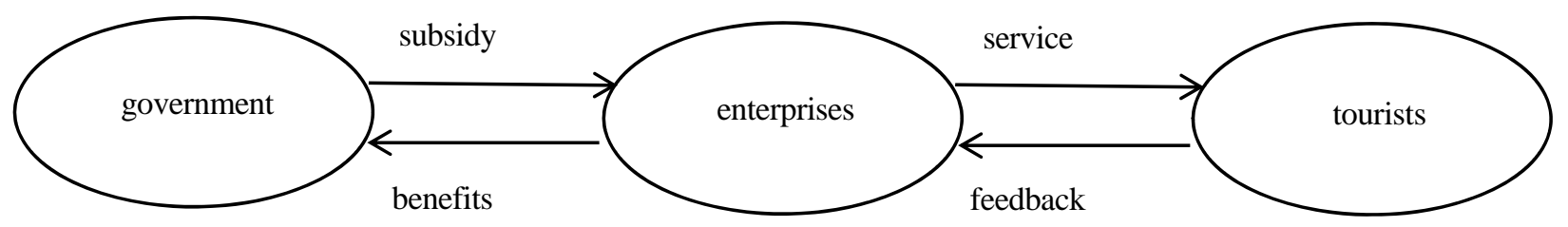

Figure 1. Smart tourism construction value creation model.

\section{Game Models}

\subsection{Gaming Between Government and Enterprises}

After the promulgation of guiding opinions on promoting the development of smart tourism, the smart tourism has experienced rapid development. However, since smart tourism is in its infancy in our country, there is no standard sample for reference. For enterprises, the cost of building smart tourism does not necessarily bring substantial benefits, so it is unwilling to invest in it. The government department's strategic choice is \{support, not support \}, once the governments choose "support" strategy, they will give subsidies $\mathrm{M}$ to enterprises. When smart tourism is constructed, the government's revenue is $R_{1}$. If government choose to not support the construction, its revenue is $\mathrm{R}_{1}^{\prime}$. Tourism enterprises' strategic space is \{construct, not construct . If the tourism enterprises declare and build smart tourism, they will get the subsidies from the government. A series of related costs of information technology and infrastructure construction invested by tourism enterprises in the smart tourism are recorded as $\mathrm{C}$, and the expected return is $\mathrm{R}_{2}$. The game payment matrix of government and tourism enterprises is as follows (Table 1).

Table 1. Government - Corporate smart tourism construction game payment matrix.

\begin{tabular}{|c|c|c|c|}
\hline \multirow{2}{*}{\multicolumn{2}{|c|}{}} & \multicolumn{2}{|c|}{ governments } \\
\cline { 3 - 4 } & construct & support & not support \\
\hline \multirow{2}{*}{$\begin{array}{c}\text { Tourism } \\
\text { enterprises }\end{array}$} & not construct & $\left(\mathrm{R}_{2}+\mathrm{m}-\mathrm{C}, \mathrm{R}_{1}-\mathrm{m}\right)$ & $\left(\mathrm{R}_{2}-\mathrm{C}, \mathrm{R}_{1}^{\prime}\right)$ \\
\cline { 2 - 4 } & $(0,0)$ & $(0,0)$ \\
\hline
\end{tabular}


It can be seen from the payment matrix that when $R_{1}-m>0, R_{2}-C>0$, the game matrix has an equilibrium solution. If $\mathrm{R}_{1}-\mathrm{m}>\mathrm{R}_{1}^{\prime}$, then the government will take supportive policies; Similarly, if $\mathrm{R}_{2}+\mathrm{m}-\mathrm{C}>0$, tourism development enterprises will choose to build smart tourism. Therefore, when $C-R_{2}<m<R_{1}-R_{1}^{\prime}$, the tourism development enterprises and the government achieve a balance.

\subsection{Game Between Tourists and Enterprises}

The game between tourists and tourism enterprises mainly lies in whether tourists actively participate in the construction decision-making process in the construction of smart tourism, and whether tourism enterprises actively adopt the opinions of tourists and construct smart tourism in accordance with the actual needs of tourists.

In the gradual development and improvement of smart tourism, ICTs technology can make tourist attractions better able to sense tourists' needs. Visitors can also give feedback on the construction of smart tourism after the travel ends. Being involved in the smart tourism construction need to pay extra time and effort, so there are some tourists do not want to participate. The value created by tourists and enterprises is $\mathrm{V}$, when the tourists are negatively involved, the value created by the enterprise is $V^{\prime}\left(V>V^{\prime}\right)$. The value distribution coefficient is $Q$, interaction cost is $C$, if both tourists and firms choose a positive strategy, then the interaction cost is equalized, and if only the tourism firm chooses the positive strategy, the whole interactive cost is assumed by the firm. The payment matrix is as follows (Table 2).

Table 2. Corporate -Tourists smart tourism construction game payment matrix.

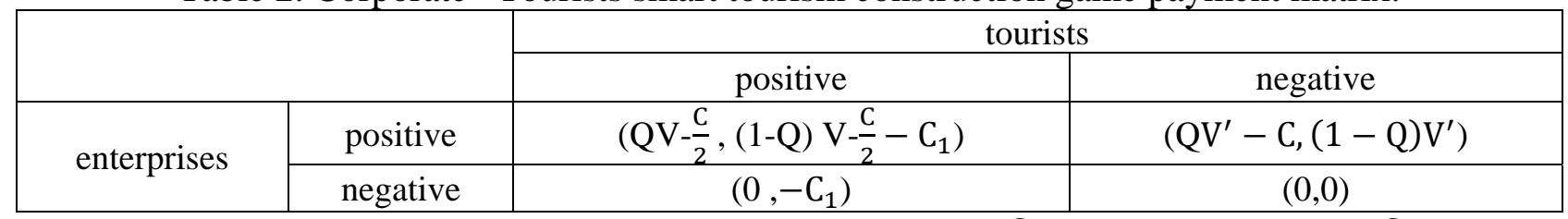

From the above payment matrix, we can see that if $(1-\mathrm{Q}) \mathrm{V}-\frac{\mathrm{C}}{2}-\mathrm{C}_{1}>(1-\mathrm{Q}) \mathrm{V}^{\prime}, \mathrm{QV}-\frac{\mathrm{C}}{2}>0, \mathrm{QV} \mathrm{V}^{\prime}-$ $\mathrm{C}>0$ are satisfied, the equilibrium solution is (positive and positive). If only (1-Q) $\mathrm{V}-\frac{\mathrm{C}}{2}-$ $\mathrm{C}_{1}>(1-\mathrm{Q}) \mathrm{V}^{\prime}$ and $\mathrm{QV}-\frac{\mathrm{C}}{2}>0$ are satisfied, the equilibrium solution is (positive, positive), (negative, negative). Therefore, whether $\mathrm{QV}^{\prime}-\mathrm{C}$ is greater than 0 determines whether the equilibrium solution is unique and is (positive, positive). $\mathrm{QV}^{\prime}-\mathrm{C}$ depends on the participation of tourists.

\section{Summary}

Specific analysis of stakeholders' role on smart tourism construction are as follows:

(1) The government owns a dominate role. In the early stage of the smart tourism, government's policy orientation and support are very important. When the subsidy $\mathrm{M}$ is within a certain range, it can promote enterprises to build smart tourism. The greater the subsidy, the more it can promote enterprises and make the game model reach a balanced and steady state. However, excessive subsidy policy can't consolidate the stability. Therefore, during smart tourism construction, governments can decide subsidy given to enterprises and thus affect the balance of the entire system. For the government, to promote enterprises to actively build smart tourism, strong financial subsidies are essential.

(2) The active construction of enterprises is very important. In the game with the government, once an enterprise chooses not to build a smart tourism, the benefits of both parties will be zero no matter whether the government chooses to support it or not. In the game between tourists and businesses, once companies choose to negatively build smart tourism, then tourists will inevitably choose a negative strategy. The results of the two games show the importance of enterprises' initiative.

(3) Tourists' inferior. Although ICTs technology makes it easier for tourists to participate in the development of smart tourism, but from the game results, tourists are still in a weak position. When the enterprises are not active in adopting tourists' opinions and suggestions, the time and effort exerted by the tourists is useless. Tourists can hardly change the stable outcome of the game model by themselves and only play a supplementary role. Although government policies play an important role 
in the initial stage, to form a long-term mechanism, the role of government must be gradually weakened and active participation of tourists must be promoted, so that the smart tourism construction is more in line with the expectations of tourists, so as to attract more tourists, thus improving the economic benefits.

\section{References}

[1]. Buhalis D, Amaranggana A. Smart Tourism Destinations [M] Information and Communication Technologies in Tourism 2014. Springer International Publishing, 2013:553-564.

[2]. Chiappa G D, Baggio R, Xiang Z, et al. Knowledge transfer in smart tourism destinations: analyzing the effects of a network structure [J]. Journal of Destination Marketing \& Management, 2015, 4(3):145-150.

[3]. Zhang Xiuqin.An empirical study on the definition and classification of smart tourism stakeholders [J]. Journal of Finance and Economics, 2017 (4): 24-32

[4]. Lian Tonghui, et al..Review on the study of smart tourism [J]. Journal of Central South University of Forestry and Technology (Social Science Edition), 2016, 10 (5): 59-66.

[5]. Zhang Lingyun, et al. Basic Concepts and Theoretical System of smart tourism [J]. Journal of Tourism, 2012, 27 (5): 66-73.

[6]. Xia W, Xiang L, Feng Z, et al. How smart is your tourist attraction? : Measuring tourist preferences of smart tourism attractions via a FCEM-AHP and IPA approach.[J]. Tourism Management, 2016, 54:309-320.

[7]. Liu Jiafeng. Tourists' Perceptive of service quality on smart tourism construction: an analysis based on web textual content [J]. Journal of Shijiazhuang University, 2016, 18 (6): 72-79.

[8]. Boes K, Buhalis D, Inversini A. Smart tourism destinations: ecosystems for tourism destination competitiveness [J]. International Journal of Tourism Cities, 2016, 2(2):108-124.

[9]. Section W. IoT Architecture for a Sustainable Tourism Application in a Smart City Environment [J]. Mobile Information Systems,2017, (2017-01-30), 2017, 2017:1-9 